\title{
Relationship between Territorial Aggression and International Criminal Court (ICC) Global Jurisdiction with Security Council of United Nations
}

\author{
Saeedeh Pirbodaghi ${ }^{1}$ \\ ${ }^{1}$ Payam Noor University, Tehran Center Branch, Iran \\ Correspondence: Saeedeh Pirbodaghi, Payam Noor University, Tehran Center Branch, Iran. E-mail: \\ saeede.pirbodaghi@gmail.com
}

Received: April 18, 2016 Accepted: June 17, 2016 Online Published: July 31, 2016

doi:10.5539/jpl.v9n6p146 URL: http://dx.doi.org/10.5539/jpl.v9n6p 146

\begin{abstract}
All nations are linked to each other by a mutual connection and their cultures make mutual heritage; nonetheless, this elegant combination will separate in a moment. Millions children women, and men are sacrificed for unimag inable disasters that human spirit has stunned suddenly during this century. In spite of obstacles facing with constituting international system based on justice, humans' fundamental rights were mentioned greatly during the World War I and II. Therefore, great determination was made to accomplish international security and peace in light of legal laws. Making United Nations, publishing human rights declaration, assigning convections such as preventing punishment of genocide and Geneva fourth conventions 1949 as complementation regulations and war rights indicate serious determination to shape international law system.
\end{abstract}

Keywords: Un ited Nations (UN), security council, juris diction court

\section{Introduction}

Today developing relationships, speed in transferring data, and technology development in all life aspects, which itself results in communications and relationships, have developed all over the world and its effects are also observed on extension crime. Our era is significantly important, because crime has passed more extensive boundaries and makes disasters than past which was only considered as aggression to people rights that has made international community and human spirit has stunned suddenly. These traits have made today governments to face with crimes being international. On the other hand, international government made international contracts and has tried to prevent criminals' impunity by crimes incremental range and necessary legal mechanis ms. In addition, governments have meta-national effect and various criterions in facing with res ulted dangers of crimes to determine nature of their courts' jurisdiction to develop national court jurisdiction to meta-national crimes by leaning on them and purchase their criminals. Obviously, these criterions encompass indexes relating committed crimes to tendentious country. Collection of these mechanisms is function of countries internal laws. It has been declared that international criminals' impunity hasn't continually been prevented chronically by increasing international crimes range and intensity ad governments' negligence on leaning on the nature of global jurisdiction to purchase international criminals who are particularly didn't have direct relationship with those governments benefits. Statute of the international criminal court includes introduction, 13 chapters, and 128 articles. Thirteenth chapter of statute have the following subjects, respectively: Creation of the Court, juris diction, admissibility and applicable law, general principles of criminal law, organization and admin istration of justice, investigation and prosecution, trial, penalties, appeal and retrial, international cooperation and mutual legal assistance, implementation, Assembly of States Parties, budget, and final conditions. Amongst, the issue of jurisdiction and admissibility proceedings, in terms of its provisions conflict with the sovereignty of states is significantly important so that issues about criminal jurisdiction were considered important and principal in Rome conference. Before discussing about aspects of jurisdiction, brief look at conception of criminal jurisdiction seems necessary. Some criterions have identified in internal law to determine realm of courts' jurisdiction which is including 5 principles. These principles include principle of territorial jurisdiction, jurisdiction based on the nationality of the perpetrator, jurisdiction based on the nationality of the victim, the real competence, and the principle of global jurisdiction. Each government can determine its courts' jurisdiction relying on one or several of these principles. In other words, law maker determines laws jurisdiction realms and 
courts or direct relationship between right to punishment and government governance right and prevention foreign criminal law execution in national courts. ICC should be coordinated with the one or several mentioned principles in spite of being international according to determination jurisdiction realm to indicate its jurisdiction limitations about internal criminals in court jurisdiction. After investigating statute regulations, it should be indicated whether statute juris diction has universal traits or is limited to a certain territorial or other determinant principles of jurisdictions.

\section{Exercising Jurisdiction about International Criminal Phenomena}

Fighting with international criminal phenomenon hasn't been possible by traditional ways of jurisdiction determination in internal courts which means territorial jurisdiction, juris diction based on nationality of victim or perpetrator, or supportive jurisdiction. Let alone the condition and obstacles of executing this principle make limitations for governments in purchasing international crimes. On the other hand, many criminals of such crimes will be supported by them if they have authorities; moreover, leaning on thes e principles is limited to certain cases that crimes happen inside territory of government, perpetrators or victims are nationals of that state, or crime happens against their main benefits. Consequently, execution of any of these principles didn't account for hu man needs for preventing from impunity of who commit crime against all hu man communities. There fore, these criminals have never been punished. The principle of universal jurisdiction includes developing jurisdiction of criminal laws enforcement than international crimes. Regarding to this principle, governments have right to purchase some criminals inside their territories without caring to know where the crimes happened, or what is victim or perpetrator nationality. The principle of universal jurisdiction is based on this assumption that some of their crimes are so nasty and evil in all humans' views whose perpetrators are considered as enemy of all nations. Therefore, each government has right to prosecution, trial, and punishment of such crimes. Another noticeable point about enforcement universal ju risdiction is accompanying judg mental and legislative jurisdiction. It means if a court of state has jurisdiction to handle allegation, this handling will be done based on laws of that state, because criminal laws have close relationship with states governance and no state will execute laws of another state in its trials. Hence, courts enforcing principle of universal juris diction about international crimes will execute laws of their subordinated government. On the other hand, internal courts have shown when internal laws doesn't explicitly assign laws for universal jurisdiction, they are not interested to judge people based on universal jurisdiction.

\section{Legitimation of Holding International Court by United Nations}

Articles 41 and 42 of UN Charter are the only articles giving authorities to Security Council to declare rights and responsibilities of governments. According to these 2 articles, council can make decisions of bringing necessities for governments.

According to the seventh chapter of chapter particularly in articles 41 and 42 in fighting against breaking international regulation and commitments by governments which endangers international peace, security council can impose administrative mandate and divide them to 2 general groups of military administrative mandate and non-military administrative mandate.

Non-military administrative mandate has been predicted an article 41 of UN chapter. According to this article, "security council can decide which mandates are necessary without need of military impose and can ask UN to do these actions. These actions may include stopping all or a part of economic re lationships and railway, marine, air, postal, telegraph, rad io, etc. communications, and breaking pol itical relationships."

According to article 42 of UN Chapter "if security council recognizes predicted actions in Article 41 is not efficient, it can act to protect peace and international security by air, sea, or land force. These actions may include de monstrations, blockade or other military, air, sea, or land operations.

In addition to extension of hu man rights break and international humanitarian laws in the mentioned region, end of cold war and motto of international modern arrangement were another factor leading Security Council by hope to obtain international peace accomplishment by executing criminal law after passing 250 hostilities in the second half of $20^{\text {th }}$ century think to establish an international juridical center in order to establish peace and security in the territory of the former Yugoslavia.

Security Council documented to the $7^{\text {th }}$ chapter and articles 39 and 41 of UN Charter to establish such court. It means intensive break of hu manitarian laws in the mentioned hostilities is an example of threat against peace and international security. In this regard, according to article 41, establishing criminal justice is considered an action to establish peace by an international criminal center. 


\section{Time Jurisdiction of International Criminal Court}

Article 126 of association states time of entry to force regulations. This article beside other articles determines accurate time of court jurisdiction coming to force. According to these articles of association, it will come to force from the first day since 60 days expiration date of deposit of the sixtieth instrument of ratification or accession in UN Secretary-General. Since 10 countries deposited ratification or accession document in UN simultaneously in April, 11, 2002, court articles of association was come to force since July, first, 2002. Obviously, court will have jurisdiction to observe committed crimes in the membered countries or by their nationals. According to part 2 of article 126 of articles of association, it will come to force to deposit document of these government since the first day to 60 days later which rectifies or access their documents to UN Security-General.

\section{Investigating Authority of Security Council in Development and Suspension the Jurisdiction of International Criminal Court}

International criminal court is obliged to have relationship with other international institutions to do its mission which is executing criminal justice to have global peace establishment. UN role as the main establisher of protecting global peace and security is more highlighted than the international organizations. In this regard, in articles of association of this court, its relationship with UN has been focused from various aspects. Reference to crime full states in court jurisdiction request to suspend investigations or prosecutions by Security Council, role of Security Council in definition of the crime of aggression, the financial relationship between the Security Council and the Court, the Security Council's role in international cooperation between States and the Court are the most important communicational aspects of Court and UN. Under Section B of Article 13 of the Statute of the International Criminal Court, in a situation where several crimes happen, Security Council can refer them to prosecutor. In this case, court finds jurisdictions of observing such crimes. Working on right to vote in Security Council after theoretical issues need investigating 2 important titles; first basis of Security Council in reference situation to court; second court juris diction basis in this state.

\section{Court Global Jurisdiction in Referring State to Security Council}

When crime consisting states related to international criminal court is referred from government or prosecutor of this court investigate it individually, the basis of court jurisdiction is clear, because it purchase starts either from the place of crime occurrence which should be one of me mbered government of article of as sociation or credit of criminal national. When Security Council refers to a situation, court jurisdiction is based on none of them, because no government satisfaction is considered as precondition of executing court jurisdiction. In other words, in this state court is universal and is not limited to a certain realm. Therefore, if a situation is found anywhere in the world consisting of a crime or crimes in court jurisdiction, the criminal, regardless of whether me mbership or consent of the territorial state, the government of the perpetrator or the victim and the accused arrested reflection, court can impose its juris diction after referring situation from security council. Th is jurisdiction of court can't be based on any other principles except principle of global jurisdiction that a criminal center may have jurisdiction on its regard.

\section{Conclusion}

The most disastrous violations of human rights and international international humanitarian law committed in the course of history by those who support the governments concerned, there is no possibility to pursue it in civil court. The principle of global jurisdiction is not also a safe support to pursue these people, because political consideration, lack of proper leg islation, lack of necessary knowledge and specialty, juridical problems such as access to reasons and resulted problems by International legal aid are always obstacles preventing from its accurate execution. If we consider criminal justice as a proper mechanisms to establish peace and assurance of human rights and international humanitarian law, their establishment is possible just under the light of an independent and powerful international criminal system. The predicted legal system in Charter of UN is to support human security and peace establishment leaning on political, oversight and a little military activities have proven their insufficiencies chronically, because it couldn't prevent bloody and destructive wars ruining human in itial and infrastructural rights after passing about 60 years. Although, it shouldn't be hoped to remove all pollutions from breaking human in itial rights just by help of international criminal system from the world, it be hoped international criminals be non-punished less than past and preventing crimes to some extent. This aim is achievable when there is permanent, powerful, independent criminal center to execute its jurisdiction by government support. Obviously, jurisdiction of case international criminal court is just considered as made situation in a certain time section. Today international criminal court made today and is committed the mentioned mission. Although, its Articles of Association process is slow, its future is promising, because 
governments are satisfied by its support and approval in recent years. This court is useful and effective when it has significant power and ability to pursue international crimes. Imposing its jurisdiction is more extensive in various aspects; however, there is more hope to get to the mentioned purpose. Although, developing court jurisdiction may make governments authorities worried about human rights and humanitarian laws breaker governments, caring human rights are better guaranteed in this way. In this way, there are some governments whose forces are involved to wars all over the world and have more chance of breaking human rights, and have more concerns about instituting one independent international criminal center.

\section{References}

A. Schabas, W. (n.d.). Article 11 Jurisdiction ratione temporize. In the Triffterer (Ed.), Otto, op.cit.p.112.

Akehurst, M. (n.d.). Jurisdiction Law, British yearbook of international law, Vol. 49, jurisdiction 9723.

Antonio, C. (2002). The Rome Statute of the International Criminal Court A Commentary. Oxford university press.

Antonio, C. (2003). international criminal law. Atford University.

Bassiouni, M. C. (1991). The Time Has Come For An International Criminal Court. Indian International and Comparative Law Review, 1(1), 1.

Bassiouni, M. C. (1999). International Criminal Investigation an Prosecutions: from Versailles to Rwanda. International Criminal Law.

Bassiouni, M. C. (2006). The Icc Quo Vadis? Journal of International Criminal Justice, $4,423$. http://dx.doi.org/10.1093/jicj/mq1022

Bassiouni, M. Ch. (1992). Crimes Against Humanity in International Law. Boston: Martinus Nijhoff.

Bergsmo, M., \& Pejic, J. (n.d.). Article 5 prosecutor. In the Triffterer(ed), Otto, op. cit. p. 378.

Bothe, M. (n.d.). War Crimes, in the Antonio, Cassese, op.cit. p.383.

Cotter, M., \& Fenrick, J. (n.d.). William and Viseur sellers, patricia and Zimmermann, war crimes. In triffterer (Ed.), op. cit. p. 181.

Cryer, R., \& White, N. D. (). The Security Council and International Criminal Court: Who's feeling Threatened? Year Book of International Peace Operation, 8.

Daniel, D., \& Nsereko, N. (1999). The international criminal court jurisdiction and related issuse. $10 \mathrm{criminal}$ forum 87 .

David, J. S. (2004). How to Turn the Tide Using the Rome Statute's Temporal jurisdiction. Journal of international Criminal Justice, 2, 28.

Hebel, H., \& Robinson, D. (1999). The International Criminal Court- the making of the Rome Statute- Issu. Negotiations. Results, edited by Roy s. lee, the Hague, published by kluwer law.

Kaul, H.-P. (2000). preconditions to the Exercise of Jurisdiction. In A. Cassese (Ed.), The Rome Statute of the International Criminal Court A Commentary (Vol. 2., pp. 584). Oxford University Press .

Morris, V., \& Schart, M. P. (n.d.). An Inside's Guide to the International Criminal Tribunal for the former Yogoslavia: a Documentary History \& Analysis (Vol. 1). 'Transnational publishers 'Inc. Irvington on Hudson New york.

Olasolo, H. (2005). The Triggering Procedure of the International Criminal Court. Marthnus Nijhoff publishers' leiden. boston.

Roy, S. L. (n.d.). the international criminal court' the making of the rome statute' Issue. Negotiations' Results.

Sal, \& Per. (n.d.). International Criminal law principles, in the S. Lee. Roy, op. cit.pp. 198-199.

Scherrer, Ch. P. (1997). Justice in Transition \& Conflict Prevention in Rwanda After the Genocide. institute for Research on ethnicity and conflict Resolution.

See, V. H., \& Robinson, D. (n.d.). Crimes With in the Jurisdiction of the Court, in the, Roy S. Lee. op. cit pp. 119-121.

Triffterer, O. (n.d.). Genocide Its Particular Intent to Destroy in Whole or in part the Group as such. Leiden Journal of International Law, 14, 402.

Webster's New Twentieth Century Dictionary, Seconded, Simon and Schuster, 1990, p.993. 
Werle, G. (2005). Principles Of International Criminal Law. Netherland, T.M.C Asser press.

William, A. S. (2000). Genocide in International Law, the Crime of Crimes. Cambridge university press.

Yves, B. (1999). Judging War Criminals. ST. MARTIN'S Press. INC, first published in the united states of American.

Zagaris, B. (1995). War Crimes Tribunal in Former Yugoslavia in the, Richard D.Atkins Transational Criminal, Martinus Nijhoff publishers, and international Bar Association.

\section{Copyrights}

Copyright for this article is retained by the author(s), with first publication rights granted to the journal.

This is an open-access article distributed under the terms and conditions of the Creative Commons Attribution license (http://creativecommons.org/licenses/by/4.0/). 